\title{
'Arthritis' in Byzantium (AD 324-1453): unknown information from non-medical literary sources
}

\author{
John Lascaratos
}

\begin{abstract}
Objective-To compile and analyse information contained in non-medical texts of the Byzantine historians and chroniclers concerning arthritis, and to clarify the first use of Colchicum autumnale in the treatment of gout by the fifth century physician, Jacob Psychristus.

Conclusions-This material gives an indication of the problem of arthritis and, in particular, a disease resembling gout that tyrannised a great number of the population in the Byzantine Empire (AD 324-1453). Contemporary historians and chroniclers maintain that the main causes of gout ('podagra') were the overconsumption of alcoholic drinks and food. Most relevant texts include anxiety and heredity among the aetiological factors of the disease. The incidence of this group of diseases among the Byzantine Emperors (it is certain that 14 of a total of 86 had a form of arthritis) and other officials of the State indicates that these diseases were a possible factor in certain political and military difficulties of the Empire.
\end{abstract}

(Ann Rheum Dis 1995; 54: 951-957)

Most Byzantine physicians described several types of arthritis that resemble rheumatoid arthritis, chronic deformans polyarthritis, and gout. Significant information concerning these diseases is provided by the Byzantine physicians Oribasius (fourth to fifth century) and Aetius Amidenus (sixth century). ${ }^{1}$ Leo Iatrosophisha, another important physician of this era (ninth century) classified the several types of arthritis according to the definitions given by the previous physicians, and supported the belief that the disease was produced when the 'phlegm or the bile concentrate in the joints'. More particularly, in his opinion, if these humours concentrated in all the joints of the body, arthritis appeared, while if they concentrated in the feet, podagra (gout) appeared; finally, if the humours collected in the ischion joint, the disease took the form of ischias (sciatica). ${ }^{2}$ It is clear that these opinions were based on the Hippocratic conception of humoural pathology (the doctrine of the humours-blood, phlegm, black bile, and yellow bile). ${ }^{3}$
Many ancient and Byzantine physicians dealt with the definition, aetiology, and treatment of arthritis; among them were Rufus from Ephesus (first century AD), Alexander of Tralles (sixth century AD), Paul of Aegina (seventh century AD), ${ }^{4}$ and Demetrius Pepagomenus, personal physician of Emperor Michael VIII Palaeologus (1261-81), who wrote a special treatise concerning podagra. ${ }^{5}$

In this paper, information about the arthritis of certain personalities of that epoch, which is to be found in the texts of Byzantine historians and chroniclers, is examined. It must be noted that some historians, such as Anna Comnena and the philosopher and tutor Michael Psellus, had studied medicine. The latter, indeed, had practised successfully, as he maintained. ${ }^{16}$ These two historians had excellent knowledge of the medical theories of their time: thus official opinions of diseases, and especially of arthritis, are reflected in their descriptions. The remaining historians and chroniclers, however, reveal the most widely practised views of the age, which were not always in harmony with official scientific medicine. ${ }^{1}$

The rheumatoid arthritis of Emperor Constantine IX Monomachus (1042-1055), which was described by Caughey, ${ }^{7}$ is well known. Using the histories and chronicles of Byzantine writers, the present paper will extend Caughey's work by demonstrating the existence of something like gout or arthritis among certain Emperors and prominent officials of the Byzantine Empire. It will describe the contemporary explanations for this group of diseases, and show that these diseases were implicated in certain political and military difficulties.

\section{EMPERORS}

Of the 86 Byzantine emperors (AD 326-1453), 14 suffered from arthritis:

\section{Constans I (337-350)}

Constans, brother of Emperor Constantine and King of the Western Empire, suffered, according to the chronicler Zonaras, ${ }^{8}$ from 'continuous arthritis, which was a result of insatiable pleasures, fatigue from hunting, his sexual licentiousness and his dietary excesses'. On the basis of this information we may assume that his disease was gout. It is worth 
mentioning that overeating was thought to be a cause of this disease; even more so, were sexual excesses and anxiety. These views are in accordance with Hippocratic ${ }^{3}$ and Galenic $^{9}$ concepts.

\section{Marcian (450-457)}

On the evidence of many Byzantine writers, Marcian (fig 1), after his Coronation, suffered from a disease described as 'pain in the feet, which so affected them that he could not move' (possibly gout). This disease lasted seven years and in the final stages worsened because of his anxiety, according to the opinion of the same Byzantine writers. $^{8}$ 10-12

\section{fustinian I (527-565)}

Justinian I (front cover) had arthritis of the knee, with strong pains which appeared periodically. According to the contemporary historian Procopius, ${ }^{13}$ 'Because of the accumulation of rheum in the knee the severe pains made him sorrowful and forced him to undergo a strict diet, thus he avoided wine, bread and other food and used to eat greens, mostly wild, and drank only water. Often, at night, his pains in the knee did not let him sleep. The disease once worsened so much that he was obliged to abandon recognised medicine and to turn to the miraculous power of the forty martyrs of Melitine'. From Procopius' text, it seems that the historian (who belonged to the Emperor's circle) connected the disease with the doctrine of the humours that was prevalent during this era. From this idea (accumulation of rheumthat is, humour-in the knee), and the dietary restrictions, we may deduce that the historian is hinting at crises of gout. This conclusion is further supported by the information that Justinian was pycnic-'fat, round-faced and red-faced'. ${ }^{13}$

\section{Fustin II (565-578)}

Justin II, the successor to Justinian I, suffered from crises of arthritis-or so it seems from the words of the historian Theophanes: ${ }^{14}$ 'he felt pain in his feet which prevented him from moving and therefore was confined to bed most of the time'. According to Leo Grammaticus, ${ }^{11}$ he suffered from obesity. The

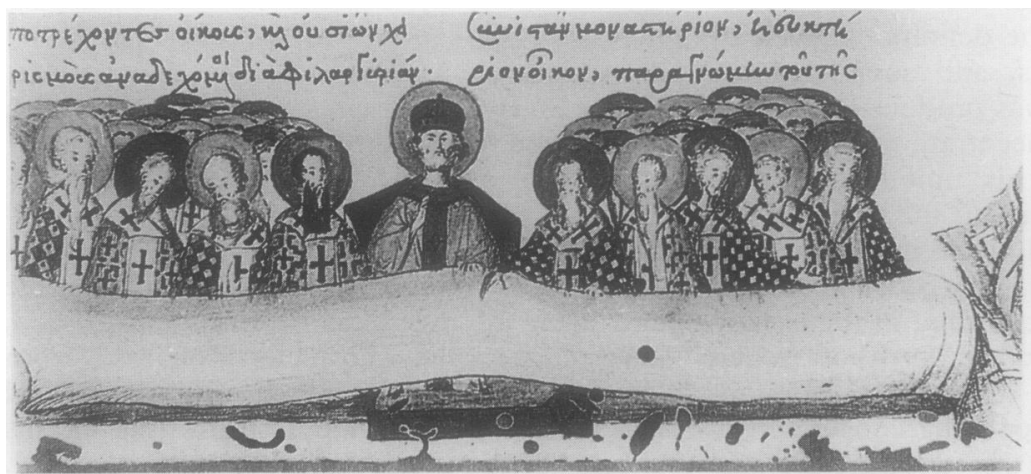

Figure 1 The Emperor Marcian among the bishops at the Synod of Chalcedon (AD 451). (Miniature of a sixteenth century manuscript of the Vatopedion Monastery of Mount Athos.) chronicler Zonaras ${ }^{8}$ attributed a great crisis of his disease to his sorrow at the occupation of the castle of Dara. This information suggests that this condition may well have been gout.

\section{Maurice (582-602)}

An acute crisis of gout must have been the indirect cause of Maurice's death at the age of 63, which resulted in accession to the throne of the tyrant Phocas. When the latter proclaimed himself Emperor and invaded Constantinople, Maurice (fig 2) disguised himself by changing into simple clothes instead of imperial finery, and tried to escape to Asia Minor. He could not progress further than the church of St Autonomus, which was 150 stages from Constantinople, because, according to historian Theophylactus, ${ }^{15}$ an acute arthritic crisis immobilised him, with the result that the new Emperor arrested him and had him killed. Theophanes ${ }^{14}$ noted that 'arthritic diseases attacked him that night, which were called podagra and chiragra (pain in the joints of the fingers), obliging him to stay immobile'. Possibly it was a crisis of gout, despite the information that he was eating little and sexually restrained. ${ }^{16} 17$ It may indeed have been the Emperor's first attack because, as is known, the first attacks of this disease commonly begin at night. ${ }^{18}$ This is supported by a lack of information from the historians concerning any previous crises.

\section{Phocas (602-610)}

The new Emperor, the tyrant Phocas (fig 3), also showed signs of arthritis, which was called 'podagra' by Pseudo-Codinos. ${ }^{19} \mathrm{He}$ asked the assistance of Saint Theodore of Syceon ${ }^{20}$ in relieving his pains. In exchange, Saint Theodore requested that he should stop his tyrannical behaviour. When he recovered from the crisis, however, he forgot his promise. ${ }^{19}$ From the information of Pseudo-Codinos, it appears that the Emperor Phocas must have

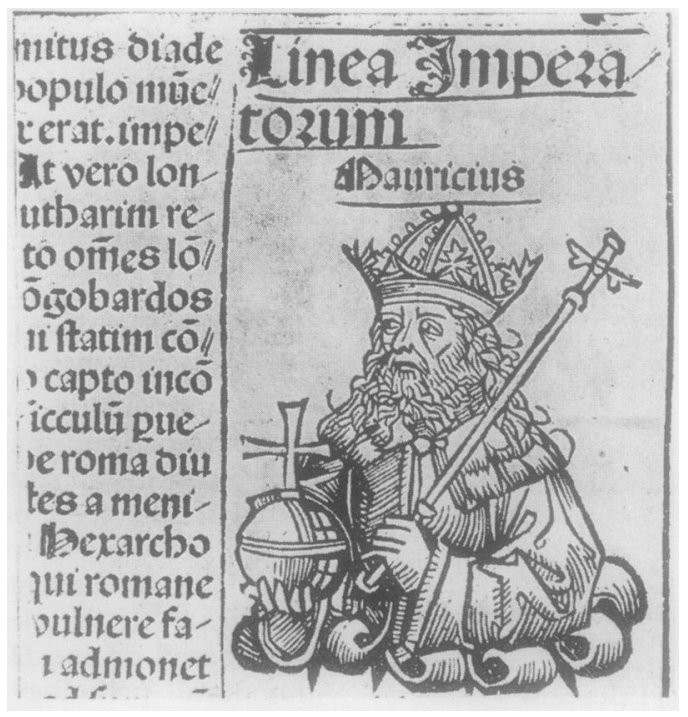

Figure 2 The Emperor Maurice. (Woodcut from Hartmann Schedel, Liber Chronicarum, Nurenburg 1493.) 


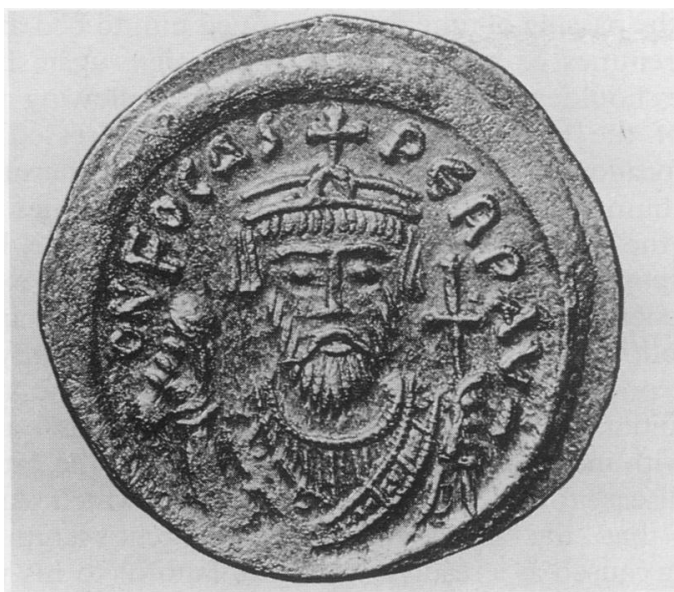

Figure 3 The Emperor Phocas. (Gold coin of his era, Museum of Numismatics, Athens.)

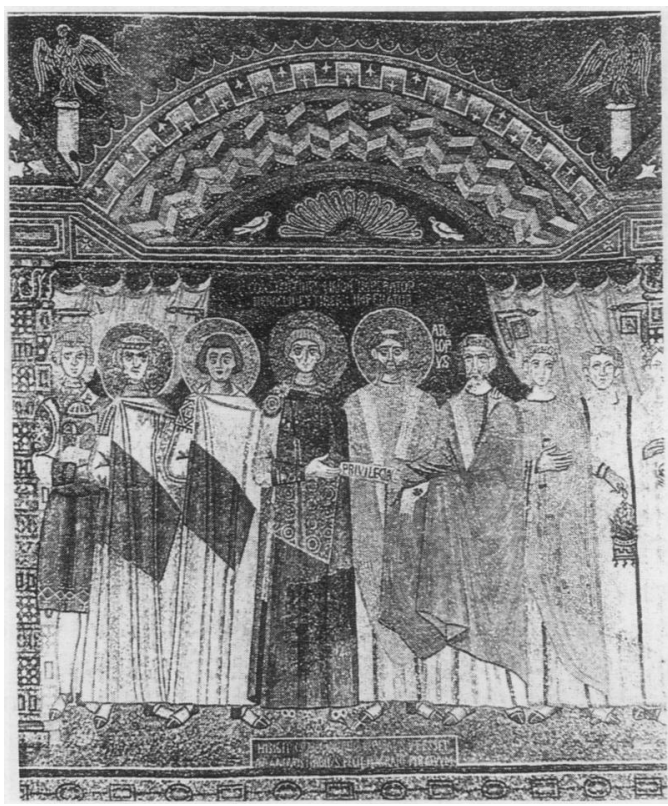

Figure 4 The Emperor Constantine IV among other members of his court. (Mosaic of St Apollinarius, Ravenna.)

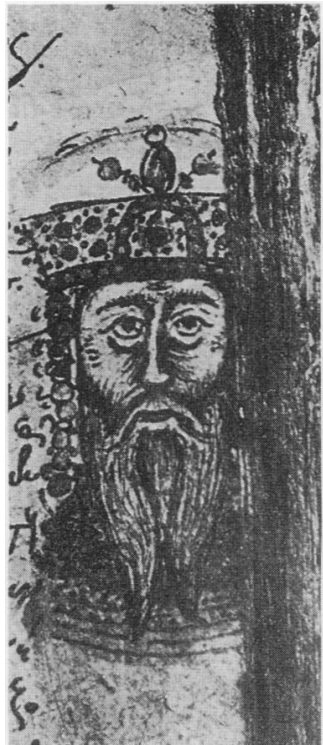

Figure 5 Constantine VIII. (Miniature of a fourteenth century Codex of the Estense Library, Modena.) had gout. This is further supported by the text of Leon Grammaticus, ${ }^{11}$ who, in addition, characterised him as a drunkard. It is known that the Byzantine physicians believed, as does current medicine, ${ }^{18}$ that the consumption of alcohol constitutes an important factor in the development of gout, and this belief influenced the ideas of Byzantine writers. ${ }^{1}$

\section{Constantine IV Pogonatus (668-685)}

The arthritis suffered by Constantine IV (fig 4) was the cause of a shameful defeat for the Empire. ${ }^{1}$ According to the writers Theophanes, ${ }^{14}$ Nicephorus, Bishop of Constantinople, ${ }^{21}$ and Zonaras, ${ }^{8}$ when he was on a campaign, severe pain from an acute crisis of 'podagra', obliged him to be carried to the town of Mesembria for treatment and baths. $\mathrm{He}$ ordered his generals to continue the battles against the Bulgarians, but his absence was misunderstood and the rumour spread that he had deserted, with the result that his army suffered a heavy defeat. ${ }^{21}$
Constantine VIII (1025-1028)

The historian and physician Psellus described Constantine VIII (fig 5) as 'tall, of great bodily size, greedy, with a large stomach which shows he used to eat very much, licentious, capable of cooking rich spicy foods combining colours and aromas and whatever else attracted the appetite. From his slavery to food and erotic pleasures, a disease of the joints attacked him'. ${ }^{6}$ According to Psellus, when pain struck his feet, Constantine was unable to walk and for this reason he preferred to move on horseback. In between the crises he took an active part in the horse races at the Hippodromus at Constantinople. A more recent chronicler, Manasses ${ }^{22}$ (fourteenth century), analysed his habits, writing that he haunted richly laden tables and kept pleasant company with loose women of the theatre, despite his great age (he was 70 years old when he acceeded to the throne).

\section{Constantine IX Monomachus (1042-1055)}

The rheumatoid arthritis suffered by Constantine IX (fig 6) was described by M Psellus, on whose text Caughey ${ }^{7}$ based his description. More than that, the clinical picture of the Emperor was described and completed by J Zonaras, ${ }^{8}$ who characterised the disease as 'arthritis in which the rheum initially attacked the feet of the emperor, so impeding his steps and even his standing upright to such a degree that, if he wished to move, either he proceeded with difficulty or

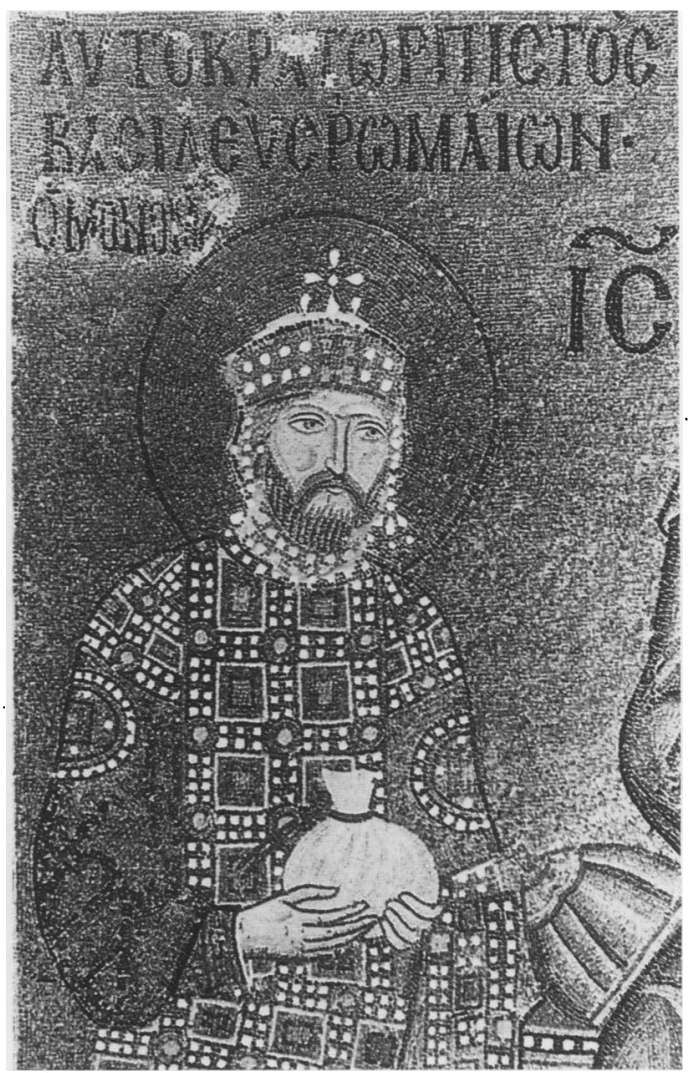

Figure 6 Constantine IX Monomachus. (Mosaic of St Sophia, Constantinople.) Only the head belongs to the Emperor: after the death of his wife Zoe's previous husband, his head was replaced by that of Constantine, and the inscription altered (as can be seen in the illustration). 
others carried him. With the passing of time the disease attacked the extremities of his hands and after that reached the shoulders and finally affected all the joints of the body, causing paresis, withering and dislocation'. This chronographer followed the humoural pathology for his interpretation of the disease. Furthermore, he identified as responsible for this condition, the state of anxiety resulting from the conspiracies of Theodora (later Empress of Byzantium) to obtain power. J Skylitzes, ${ }^{23}$ M Glykas, ${ }^{24}$ Michael Attaliota, ${ }^{25}$ and Theodore Scutariotis ${ }^{26}$ provide us with incomplete information, considering the disease to be 'podagra' (gout). They stressed that the Emperor, exhausted by the suffering caused as a result of the disease, died from an additional pleurisy. Given that the appearance of pleurisy during the life of a patient suffering from rheumatoid arthritis is well known (although this becomes evident more frequently at postmortem examination $^{18}$ ), it is possible that the Emperor's pleurisy was of rheumatoid aetiology.

\section{Alexius I Comnenus (1081-1118)}

The founder of the dynasty of the same name, Alexius I Comnenus (fig 7) suffered from 'arthritis' for many years. His daughter Anna Comnena, in her work Alexias, ${ }^{27}$ expressed the medical opinion of the time and maintained that the cause of the arthritis was not hereditary, because none of her ancestors had the same disease. Furthermore, in her opinion, dietary irregularities were not responsible because he was moderate in his eating habits. The beginning of the disease was attributable, according to Anna, to an earlier wound of the knee, when an opposing rider hit the Emperor's knee during a game. Another cause was believed to have been his worries about his high responsibilities. In time the crises became continuous, with severe pains in the feet that

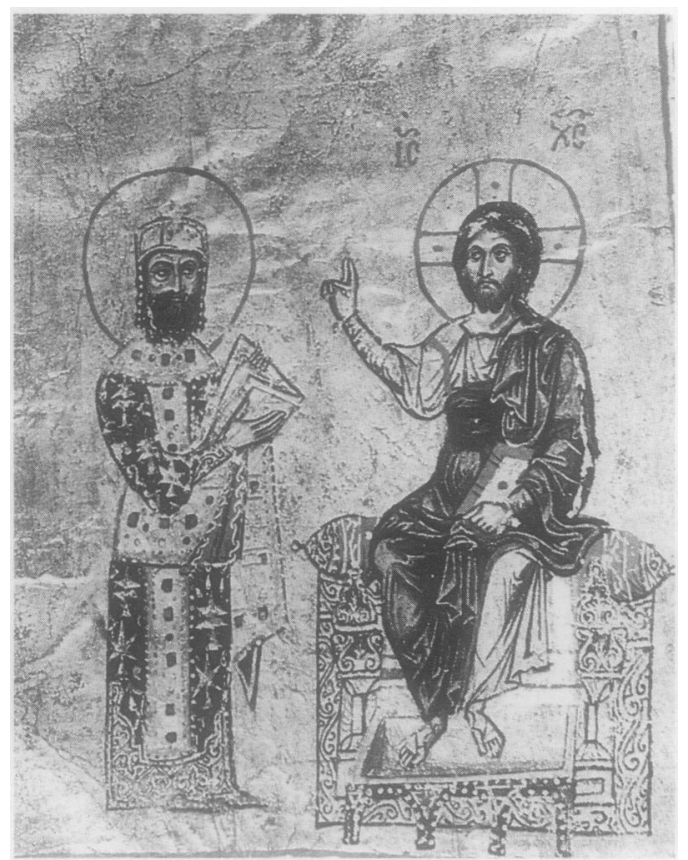

Figure 7 Alexius I Comnenus, being blessed by fesus. (Miniature of a twelfth century manuscript, Vatican Library.) confined him to bed and obliged him to cancel his compaigns against Sultan Suleiman. Anna Comnena, following the theory of humoural pathology, expressed the opinion that the accumulation of harmful humours (rheum) at the lower extremities was responsible for the disease; furthermore, her therapeutic methods were based on the expulsion of the harmful humours, with the application of cathartics, phlebotomy, and physical exercises. Anna's opinions about the arthritis coincided with those of Zonaras ${ }^{8}$ and Glykas ${ }^{24}$-with the exception that the latter revealed a cause of the disease which Anna, as the Emperor's daughter, kept secret: namely, that the patient was unfaithful to his wife and enjoyed sexual pleasures, and only in recent times had been obliged to be confined to bed (because of his 'podalgia') and to become faithful to the Empress. From Anna's text it can be concluded that Alexius presented a traumatic arthritis and gout. The diagnosis of the first form of the disease can be deduced from the previous nature of his injury and that of the second form from the aetiological opinions of that time, the affected joints, and the causes which were believed to be to blame, namely heredity (gout was then also considered as a familial disorder), dietary irregularities (obesity, also recognised today as an associated condition), ${ }^{18}$ anxiety, and sexual excesses.

Isaac II Angelus (1185-1195 and 1203-1209)

Isaac (fig 8), suffered from 'arthritis of the hands, which appeared to have withered fingers', according to the Byzantine writers Nicetas Choniates ${ }^{28}$ and Theodore Scutariotis, ${ }^{26}$ and from 'arthritis and podagra', on the evidence of the chronicler Ephraem. ${ }^{29}$ In the light of this information, it may be supposed that he suffered from gout.

\section{Alexius III Angelus Comnenus (1196-1203)}

Nicetas Choniates, ${ }^{28}$ writing of Alexius (fig 9), confirmed that, 'the joints of the body suffered during certain periods. The joints of the feet were affected worst due to the accumulation of bad materia which caused unbearable pains and resulted in immobility of the patient because of inflammation. This condition was frequently accompanied by high fevers.' On one occasion he was gripped by such unbearable pain that he dismissed his physicians, closed the doors of his room, and applied red hot iron cauteries, believing that the pain would be relieved. Naturally, this cauterisation caused burns to his legs and much more pain, and the physicians were summoned urgently. ${ }^{28}$ His problem was chronic and, as historian Choniates maintained, it disrupted his campaigns because he could not easily stand on his feet. ${ }^{28}$ The historian Theodore Scutariotis ${ }^{26}$ adds that the physicians treated Alexius with systematic alternate day application of cathartics, obviously to expel the harmful humours. It may be that Alexius III suffered from gout, in view of the evidence of the location of the disease, the aetiology, and the therapeutic treatment administered. 


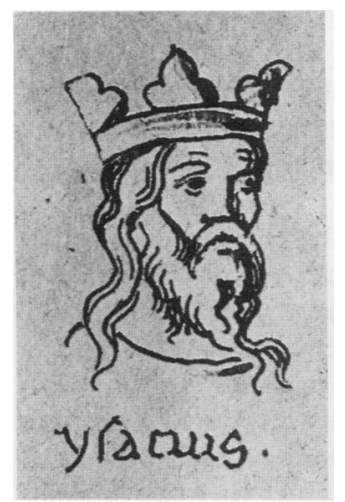

Figure 8 Isaac II Angelus. (Miniature of a fourteenth century manuscript, Marciana Library, Venice.) fohn V Palaeologus (1341-1391)

John V (fig 10) also suffered, according to historian Chalcocondyles ${ }^{30}$ from 'podalgia' (=podagra) to such a degree that he was often unable to stand up straight. Historian M Doukas ${ }^{31}$ maintained 'he was unable to

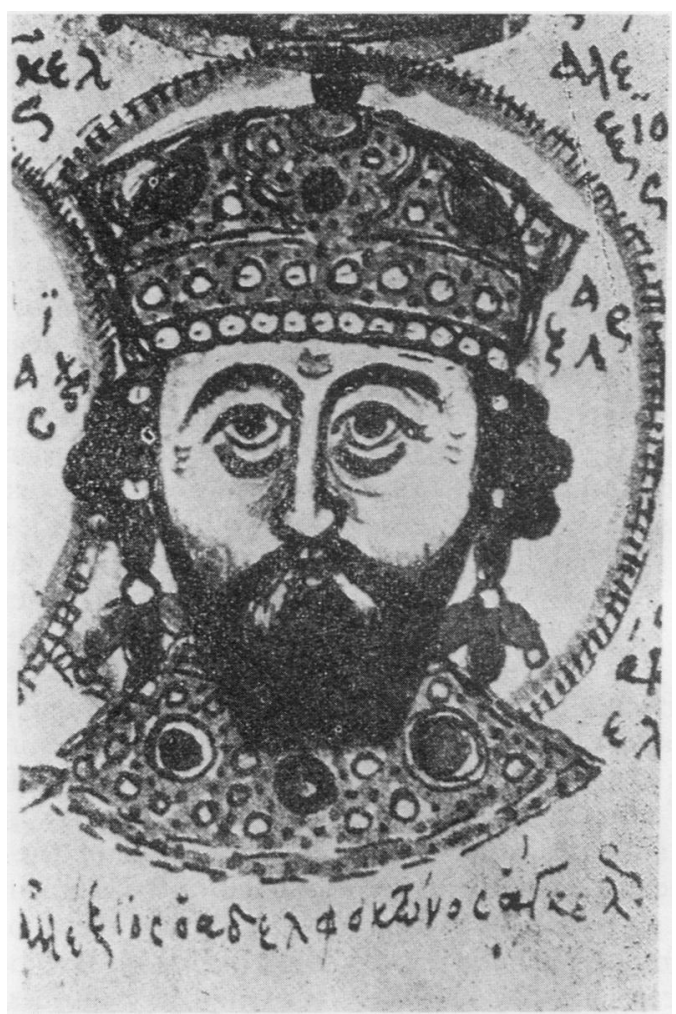

Figure 9 Alexius III Angelus Comnenus. (Miniature of a fourteenth century Codex of the Estense Library, Modena.)

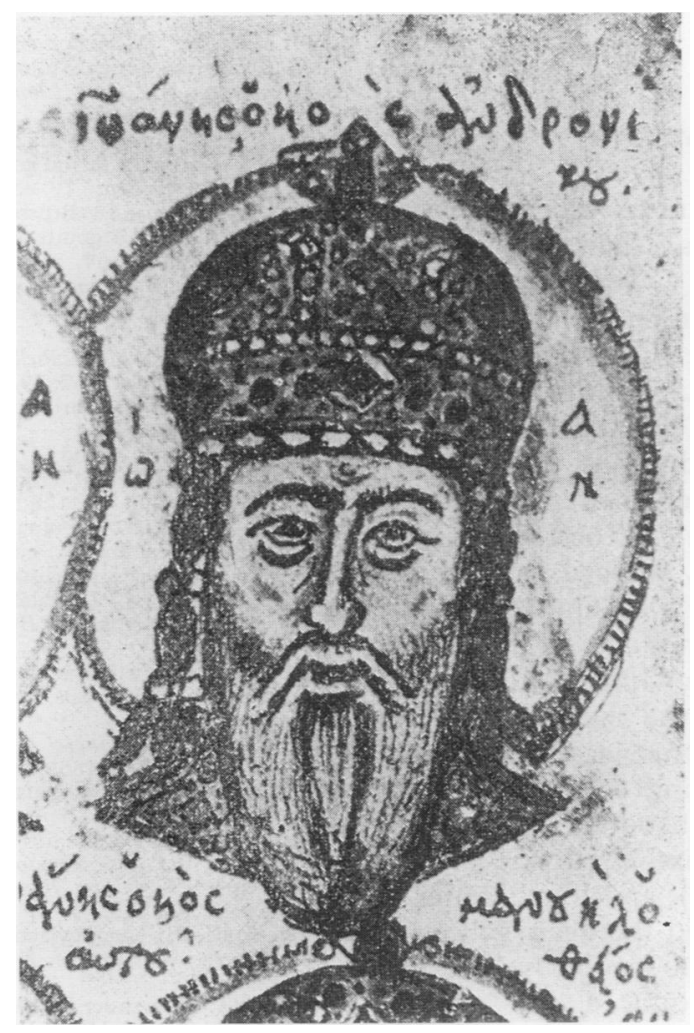

Figure 10 fohn V Palaeologus. (Miniature of a fourteenth century Codex of the Estense Library.) undertake any military action against the Turks for the rest of his life because he was bedridden with serious pains in the feet, half-dead and this disease was caused by overconsumption of food and drink and voluptuousness'. Indeed, the same historian referred to the fact that, as a result of his disease, John $\mathrm{V}$ was obliged to execute the demand of Sultan Bajezit I to demolish the castle near the Golden Gate of Constantinople (AD 1391). The definition of the disease as 'podalgia' by the two historians, and the information concerning dietary and sexual excesses direct our minds to suspicion of gout.

\section{Fohn VIII Palaeologus (1425-1448)}

John VIII (fig 11) suffered from arthritis for many years and, according to $M$ Dukas, ${ }^{31}$ he expired during a crisis at the age of 65 . The same historian attributes the disease to John's anxieties resulting from religious disputes and the death of his wife.

STATE OFFICIALS AND CHURCH DIGNITARIES

The Logothetes Theodore Castamonitis, who was the real governor of the Empire when his nephew Isaac II Angelus was on the throne, suffered from arthritis ('a disease due to bad materia which collected in the joints of the body', in the words of the historian, Choniates), and had frequently to be carried on a stretcher - even inside the palace-to meet and have discussions with the Emperor. ${ }^{28}$

Magister Paulinus suffered a crisis of 'podagra' on the day of Epiphany and which confined him to bed. ${ }^{10} 32$

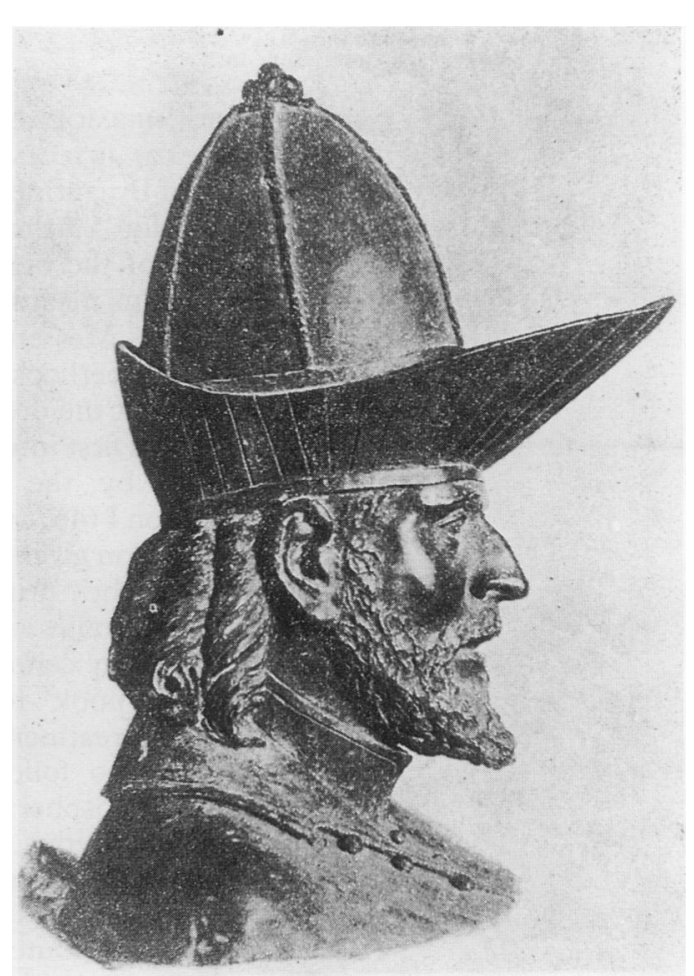

Figure 11 fohn VIII Palaeologus. (Copper bust of fifteenth century, Borgiano della Propaganda Museum, Rome.) 
Nicephorus Humnos, who was Mesazon (a title corresponding to that of Prime Minister) during the reign of Andronicus II (1282-1328), was obliged to retire from his duties because of his 'podagra'. A contemporary historian refers to the fact that, in a battle against the French of Charles d'Anjou that took place in Sorei during the reign of Michael VIII Palaeologus (1259-1282), whenever the 'Grand Seigneur' John was hit by a lance he fell, because he could not support himself well as he suffered from 'pain of the feet' ${ }^{34}$

Also mentioned as suffering from 'podagra' are the Sovereign of Melenico, Nicholas Litovois, the Domesticus of the Empire of Trapezounda, Gregory Meizomates (1341-1350), the Despot (Sovereign) of Mystras Theodore Palaeologus (1381-1407), the Patriarch John Glykes, The Patriarch Athanasios I, and the Archbishop of Achrida (Bulgaria) Theophylactus. The last of these stated in one of his letters that he suffered from 'ischias'.1

\section{OTHER LEADERS WITH ARTHRITIS}

The Byzantine writers afford further information about the diseases of the Sultans of that period. In the Battle of Ankara (AD 1402), Bajezit I (1347-1403) suffered a crisis of arthritis in hands and feet ('podagra', in the words of the historian) and for this reason was captured by Tamburlaine. For the same reason, he curtailed his campaign against the Hungarians (AD 1396) and returned to his own country. ${ }^{30}$ Bajezit II (1446-1512) was confined to bed for long periods, 'badly affected by severe rheumatism', as Scutariotis states, ${ }^{26}$ which was why he abdicated in favour of his $\operatorname{son}^{26}$

\section{THE DRUG 'HERMODACTYLUS'}

(= COLCHICUM AUTUMNALE)

The texts of Byzantine writers refer to the main medicine for arthritis, hermodactylus-a constituent of the herb Colchicum autumnale. Hermodactylus means, in Greek, the 'finger of Hermes'- the Messenger God of the Ancient Greeks - thus perhaps suggesting the speed of movement that the drug provided for patients. This drug was first introduced in the treatment of podagra by the personal physician of Emperor Leon I (457-474), Jacob Psychristus. ${ }^{35}$ The information given by Wallace, ${ }^{36}$ who maintained that the drug was introduced by Alexander of Tralles, is not correct: Alexander of Tralles (sixth century) himself referred in his 'eleventh book' to the fact that he was following the treatment that Jacob Psychristus introduced (also following a pharmaceutical idea of the philospher Theodotius of the third century AD) ${ }^{37}$ Aetius (sixth century), Paul of Aegina (seventh century), and John Actuarius (fourteenth century) used the drug, following the treatment attributed to Jacob Psychristus. ${ }^{38}$ (This drug was reintroduced into clinical medicine in 1763, by the physician Anton Störck, of the Vienna School. ${ }^{36}$ )
The Byzantine writer Evagrius referred to the death of Gregory, Bishop of Theopolis (AD 594), who suffered from serious podagra, because he drank an excess dose of hermodactylus to relieve his pain. ${ }^{1}$

The information above suggests that 'arthritis' was widespread in Byzantium. Although there are no specific statistics for the incidence of the disease in Byzantine times, the frequency, revealed in our research, with which contemporary texts referred to arthritis generally and to gout in particular in comparison with other diseases, in itself implies that the disease was frequent. The occurrence of the disease in 14 of 86 Emperors over a long period of time, bearing in mind that the majority of them were not related (because there was no single dynasty), may be indicative of its prevalence; there is, in addition, a clear indication in the text of Zonaras (eleventh century), ${ }^{8}$ in which it is stated that he believed podagra to be a common disease. This is in agreement with a general observation made by the historian Theophylactus Simocattes (sixth century), who supported the belief that podagra was frequent among the inhabitants of Constantinople, causing considerable problems and making them 'unfortunate'. ${ }^{15}$

In conclusion, it appears that a great number of Sovereigns of the Byzantine Empire and officials of the State and leaders of the Church suffered from a form of arthritis, which in most cases seems to have been gout. Almost all the contemporary sources support the conclusion that the latter disease was a result of the overconsumption of alcoholic drinks and food. A significant role of anxiety and heredity is also stressed in most of the texts.

1 Lascaratos J. Historical information for arthritis in Byzantine Times. Byzantine Studies 1992; 4: 295-332.

2 Ermerins F Z, ed. Leon's the philosopher and physician. Synopsis of medicine. Lugduni Batavorum: Anecdota Medica Graeca, 1840; 209.

3 Byl S. Rheumatism and gout in the Corpus Hippocraticum. In: Appelboom T, ed. Art, history and antiquity of rheumatic diseases. Brussels: Elsevier, 1987; 84-6.

4 Jeanselme E. La goutte à Byzance. Bull Soc Fr Hist Med 1920; 14: 137-64.

5 Neuburger M. History of medicine [transl. E Playfair], vol I. London: H Frowde, Hodder and Stoughton, 1910 324-43.

6 Renauld E, ed. Michel Psellos, Chronographie, vol I. Paris: Les Belles Lettres, 1967; 29.

7 Caughey D. The arthritis of Constantine IX. Ann Rheum Dis 1974; 33: 77-80.

8 Büttner-Wobst T, ed. I Zonaras, Annalium, vol III. In Corpus Scriptorum Historiae Byzantinae. Bonn: Weber 1897; 32, 113-21, 178, 227-8, 648-51, 760-2.

9 Lopez Forez J A. Rheumatism, arthritis and gout in Galen. In: Appelboom T, ed. Art, history and antiquity of rheumatic diseases. Brussels: Elsevier, 1987; 84-6.

10 Dindorf L, ed. I Malalas, Chronographia. In: Corpus Scriptorum Historiae Byzantinae. Bonn: Weber, 1831; 356-68.

11 Bekker I, ed. Leo Grammaticus, Chronographia. In: Corpu Scriptorum Historiae Byzantinae. Bonn: Weber, 1842; $112-43$.

12 Tafel $\mathrm{T}$, ed. Theodosi Meliteni qui fertur Chronographia. Munich: Franz, 1859; 79.

13 Dindorf L, ed. Procopius, De Aedificiis, Historia Arcana, vol III. In: Corpus Scriptorum Historiae Byzantinae. Bonn: vol III. In: Corpus Scriptorum

14 Niebuhr B G, ed. Theophanes Chronographia, vol I. In Corpus Scriptorum Historiae Byzantinae. Bonn: Weber, $1839 ; 381,466$.

15 Bekker I, ed. Theophylacti Simocattae Historiae. In: Corpus Scriptorum Historiae Byzantinae. Bonn: Weber, 1834 332.

16 Bidez J, Parmentier L. The ecclesiastical history of Evagrius. Amsterdam: A M Hakkert, 1964; 214.

17 Nicephorus Callistus Xanthopulus. Historia Ecclesiastica, Patrologia Graeca, vol 147. Paris: J-P Migne, 1872; 345. 
18 Kelley W N, Harris E D, Ruddy S, Sledge C. Textbook of rheumatology, 4th edn, vol 1-2. Philadelphia/London, etc: Saunders, $191 ; 898,1291-336$.

19 Niebuhr B G, ed. George Codinos (Pseudo-Codinos). In: Corpus Scriptorum Historiae Byzantinae. Bonn: Weber, $1863 ; 189$.

20 Acta Sanctorum, vol II. Antverpiae: M Cnobarum, 1675; $58 \mathrm{E}$.

21 Bekker I, ed. Sancti Nicephori Patriarchae Constantinopolitani, Breviarium post Mauricium gestarum. In: Corpus Scriptorum Historiae Byzantinae. Bonn: Weber, 1837 $39-40$.

22 Bekker I, ed. Constantine Manasses, In: Corpus Scriptorum Historiae Byzantinae. Bonn: Weber, 1837; 257.

23 Thurn I, ed. I Scylitzae, Synopsis Historiarum. In: Corpus Fontium Historiae Byzantinae. Berlin: W de Gruyter, 1973 477-8.

24 Bekker I, ed. M Glycas, Chronographia. In: Corpus Scriptorum Historiae Byzantinae. Bonn: Weber, 1836; 594-9, 622-5

25 Brunet de Presle W, ed. Michael Attaliota, Historia. In: Corpus Scriptorum Historiae Byzantinae. Bonn: Weber, Corpus Scriptorum Historiae Byzantinae. Bonn: Weber,
$1853 ; 35$. Theodore Scutariotis. Synopsis Chroniki. In: $K$ Sathas,
Medieval Library, vol VII. Paris: Jean Maisonneuve, 1894; Medieval Library, vol VII. Paris: Jean Maisonneuve, 1894

27 Reifferscheid A, ed. Anne Comnena, Alexias, vol II. In: Corpus Scriptorum Historiae Byzantinae. Bonn: Weber $1878 ; 142-3,272-3$.
28 Van Dieten I A, ed. Nicetae Choniatae, Historia, vol I. In: Corpus Fontium Historiae Byzantinae. Berlin: W de Gruyter, 1975; 438-9, 496-9, 558-62.

29 Lampsides O, ed. Ephraem Aenii Historia Chronica. In: Corpus Fontium Historiae Byzantinae. Athens: Academia Atheniesis, 1990; 6993-7008.

30 Bekker I, ed. Laonicus Chalcocondylae, De rebus Turcicis. In: Corpus Scriptorum Historiae Byzantinae. Bonn: Weber, In: Corpus Scriptorum

31 Niebuhr B G, ed. Ducae Michaelis Nepotis, Historiae Byzantinae. In: Corpus Scriptorum Historiae Byzantinae. (1834;48, 223.

32 Lindorf L, ed. Chronicon Pascale, vol I. In: Corpus Scriptorum Historiae Byzantinae. Bonn: Weber, 1832; 584.

33 Schopen L, ed. J Cantacuzeni, Libri Historiarum, vol I. In Corpus Scriptorum Historiae Byzantinae. Bonn: Weber, 1828; 67 .

34 Bekker I, ed. Georgius Pachymeres, De Michaele Palaeologo, vol I In: Corpus Scriptorum Historiae Byzantinae. Bonn: Weber, 1835; 411.

35 Delpeuch A. La goutte et le rhumatisme. Paris: G Carre et $C$ Naud, $1900 ; 264-86$.

36 Wallace $S$ L Colchicum cures everything In: Appelboom ed. Art, history and antiquity of rheumatic diseases. Brussels: ed. Art, history and antiquity of rheumatic diseases. Brussels: 37 Plsevier, 1987 ; 88-90. W Braumuller, 1879; 565-71.

38 Temkin O. Byzantine medicine: tradition and empiricism. Dumbarton Oaks Papers 1962; 16: 97-115. 